Environment

\title{
Design guidelines for on-site stormwater detention
}

\section{Critérios de dimensionamento de reservatórios de detenção de águas pluviais}

\author{
Ricardo Cesar Conrado de Souza' (iD, Flávio Bentes Freire' ${ }^{10}$, \\ Michael Mannich"iD \\ 'Universidade Tecnológica Federal do Paraná, Curitiba, PR, Brazil \\ "Universidade Federal do Paraná, Curitiba, PR, Brazil
}

\begin{abstract}
The city of Curitiba-PR has a municipal decree that establishes the criteria for the design of flood detention tanks. However, these guidelines do not guarantee minimum efficiency during operation, as it may vary depending on their base area, water depth and flow regulating orifice diameter. In this research, a design method was proposed, establishing some new criteria that relate impervious areas of the lots to the tank design parameters. The efficiency definition was established with the premise that the tanks should provide the return of flows from an impervious area to its pre-urbanization scenario. This reduction was established as $70 \%$ of the peak flow in the city of Curitiba-PR. Based on simulations of flow routing with the Puls Method, the optimum geometric characteristics (volume, area, water depth and orifice diameter) of the tanks were obtained to guarantee the decrease in the peak. Comparing the results obtained from the municipal legislation design, the new method provided $n$ minimal efficiency and a decrease of $24 \%$ of the tank volume.
\end{abstract}

Keywords: Urban Drainage; Flood Detention Tanks; Puls Method

\section{RESUMO}

A cidade de Curitiba-PR possui um decreto que estabelece os critérios de dimensionamento de reservatórios de contenção de cheias. Porém, estas diretrizes não garantem eficiência mínima na sua operação, visto que a mesma pode variar em função da área de base, lâmina d'água e diâmetro do orifício regulador de vazão. Nesta pesquisa foi proposto um método de dimensionamento, estabelecendo critérios que relacionam as áreas impermeabilizadas dos lotes aos parâmetros de dimensionamento dos reservatórios. A definição de eficiência foi estabelecida com a premissa de que os reservatórios devem proporcionar o retorno das vazões oriundas de uma área impermeabilizada à sua condição de pré-urbanização. Esta redução foi estabelecida em 70\% para a vazão de pico no município de Curitiba-PR. A partir de simulações de propagação de vazão pelo Método de Puls do escoamento oriundo de áreas impermeabilizadas foi definido o dimensionamento ótimo dos reservatórios para 
atendimento à redução no pico da vazão efluente em termos do volume, área de base, altura da lâmina d'água e diâmetro do orifício regulador. Comparando os resultados obtidos pelo dimensionamento de acordo com legislação municipal houve garantia de atendimento de eficiência mínima e a redução de $24 \%$ do volume do reservatório em relação ao cálculo atual.

Palavras chaves: Drenagem Urbana; Reservatórios de Contenção de Cheias; Método de Puls

\section{INTRODUCTION}

On-site stormwater detention (OSD) or detention tanks are a facility solution of stormwater management systems for urban areas. It delays peak flow and reduces the outlet flow rate, because the release rate is controlled by water depth and a hydraulic discharge structure (frequently a bottom orifice) (CANHOLI, 2005; CUNNINGHAM et al., 2017). A proper sizing and design allow to attenuate the peak flow reducing the contribution to the urban drainage system, conditioned to the project risk assumed.

Silva Junior, Silva and Cabral (2017) studied compensation mechanisms, noting that the implementation of OSD can prevent flooding. They show the relevance of using detention devices as a solution for excess runoff of flood problems. There are several other devices that may provide peak flow attenuation and may include runoff reduction through infiltration and evapotranspiration (CUNNINGHAM et al., 2017).

The use of these hydraulic structures to control rainwater drained in urban lots is the object of international research, as in Coombes et al. (2003), Campisano et al. (2014), Sterren, Rahman and Ryan (2014), Raimondi and Becciu (2014), Sterren and Rahman (2015), and Pala, Gnecco and Barbera (2017), who simulated OSD operation related to rainwater reuse, which shows an improved of the drainage approach in relation to that generally proposed in Brazil. Calabrò and Viviani (2006), Todeschini, Papiri and Ciaponi (2012), and UDFCD (2015) also point out that detention tanks can be effective tools against water quality pollution from urban runoff. In this context, Becciu and Raimondi (2015) also studied the residence times 
on those tanks to promote guarantee the sedimentation of particles carried by precipitation.

Table 1 shows some Brazilian cities guidelines and decrees to OSD designs. All propose a rule to the volume sizing related to the impervious area applied usually for new buildings or reforms. However, they are applied for a threshold area, and are not necessary for all lots. Considering a rainfall design, some rules does not make clear why a given value is assumed and only for São Paulo and Porto Alegre a return period is stated.

Those Brazilian design guidelines (Table 1) have limitations on their use because they were proposed without considering the peak flow reduction as an objective as well the risk of failure, usually considered for a given return period on the rainfall intensity-duration-frequency equations. Additionally, it does not consider the influence of how geometry and the orifice diameter change the outflow. These characteristics should be present in the sizing guidelines, considering the OSD proposal, which is to attenuate and delay the peak flow.

According to Paik (2008), the failure of the reservoirs can be the result of the uncertainty associated to the design parameters, such as the determination of the inlet flow rate and the duration of the flow, as well as the hydrograph from the relationship established between these parameters, the reservoir base area, and the discharge coefficient of the flow regulating orifice.

Silveira and Goldenfum (2007) proposed a generalized design method where the OSD volume is obtained as the maximum difference between the inflow and outflow rates, where the outflow is defined as a target value.

Considering an urban lot, the ideal reduction of runoff would be the one in which, using an OSD, a flow equivalent to its pre-urbanization condition would be produced (DRUMOND; COELHO; MOURA, 2014). In this way, a minimum efficiency of flow reduction could be established as a permissible site discharge so high peak flows in the drainage system would be prevented after the urbanization of a given area (QUEENSLAND, 2013). From the inlet hydrographs to the OSD, it is possible to perform flow propagation simulations by the Puls Method, determining the outflow hydrograph and evaluating the system efficiency (CANHOLI, 2005; TUCCI, 2009). 
Table 1 - Some Brazilian cities decrees on OSD design and sizing

\begin{tabular}{|c|c|}
\hline City / Decree & Design guides \\
\hline $\begin{array}{l}\text { Curitiba (PR) } \\
\text { Municipal Decree } n^{\circ} \\
176 / 2007\end{array}$ & $\begin{array}{l}\text { Mandatory for impervious areas higher than } 3,000 \mathrm{~m}^{2} \text { and lots with } \\
\text { permeable areas less than } 25 \% \text {. } \\
\text { - Volume } \mathrm{V}\left(\mathrm{m}^{3}\right) \text { is calculated as } V=k i A_{I}, \text { where } \mathrm{k} \text { is a constant equal } \\
\text { to } 0.2, \mathrm{i} \text { is the rainfall intensity fixed as } 0.08 \mathrm{~m} / \mathrm{h} \text { and } \mathrm{A}_{\mathrm{l}}\left(\mathrm{m}^{2}\right) \text { is the impervious } \\
\text { area. } \\
\text { - The outlet orifice diameter is determined as a function of the } \\
\text { calculated volume ranging from } 25 \text { to } 500 \mathrm{~mm} \text {. } \\
\text { considering other units as correct it should be } 0.2 \mathrm{~h} \text { (or } 12 \text { minutes) which can } \\
\text { be interpreted as a rainfall duration. }\end{array}$ \\
\hline $\begin{array}{l}\text { São Paulo (SP) } \\
\text { Municipal Law nº } \\
16.402 / 2016\end{array}$ & $\begin{array}{l}\text { Mandatory only for lot greater than } 500 \mathrm{~m}^{2} \text {. } \\
\text { Design consider a rainfall with } 10 \text { year of return period. } \\
\text { The maximum permissible release flow rate is } Q_{\max }=0.0011 \mathrm{~A}[0.38+ \\
(D p-0.38)(1-D)] \text { given in } \mathrm{L} / \mathrm{s}, \mathrm{A}\left(\mathrm{m}^{2}\right) \text { is the lot area, and } \mathrm{D} \text { and } \mathrm{Dp} \text { are } \\
\text { indexes calculated as function of city zone occupation rules, vegetation and } \\
\text { drainage solutions and, share of permeable area. } \\
\text { - The minimal volume is should be } 6.3 \mathrm{~L} / \mathrm{m}^{2} \text { for the total lot area. }\end{array}$ \\
\hline $\begin{array}{l}\text { Porto Alegre (RS) } \\
\text { Municipal Decree } n^{\circ} \\
18.611 / 2014\end{array}$ & $\begin{array}{l}\text { - All lot with impervious areas has a maximum permissible release flow } \\
\text { rate of } 20.8 \mathrm{~L} / \mathrm{s} \text {.ha to the urban drainage network. Lots with total area lower } \\
\text { than } 600 \mathrm{~m}^{2} \text { can receive exemption. } \\
\text { - For lots with area up to } 100 \text { ha the OSD volume } \mathrm{V}\left(\mathrm{m}^{3}\right) \text { is calculated by } \\
V=0.0425 A_{I} \text { where } \mathrm{A}_{\mathrm{I}}\left(\mathrm{m}^{2}\right) \text { is the impervious area. } \\
\text { - } \quad \text { por areas greater than } 100 \text { ha the OSD should be design for a return } \\
\text { period of } 10 \text { years. }\end{array}$ \\
\hline
\end{tabular}

Rio de Janeiro (RJ) Municipal Decree $\mathrm{n}^{\circ}$ 23.940/2004

Not necessary for areas up to $500 \mathrm{~m}^{2}$.

- $\quad$ For areas greater than $500 \mathrm{~m}^{2}$ the OSD volume is calculated as $V=$ $k A_{I} h$, where $\mathrm{k}$ is attenuation coefficient with value $0.15, \mathrm{~A}_{\mathrm{I}}\left(\mathrm{m}^{2}\right)$ is the impervious area, and $\mathrm{h}(\mathrm{m})$ is the rain depth assuming values of 0.06 or 0.07 depending on the planning area.

- $\quad$ Rain depth does not show the rainfall intensity and duration assumed.

Mandatory for lots higher than $500 \mathrm{~m}^{2}$, built or not, with impervious areas higher than $25 \%$.

- $\quad$ The construction of the reservoirs is not required for the lots in which their rainwater does not impact the public drainage system, proven by infiltration and geotechnical percussion tests.

Recife (PE) Municipal Law $\mathrm{n}^{\circ}$ $18.112 / 2015$
- Volume $\mathrm{V}\left(\mathrm{m}^{3}\right)$ is calculated as $V=k i A$, where $\mathrm{k}$ is an attenuation coefficient equal to 0.25 , $i$ is the rainfall intensity defined as $0.06 \mathrm{~m} / \mathrm{h}$ and $A$ (ha) is the total area of the lot.

- The outlet orifice diameter is determined as a function of preurbanization flow ( $\mathrm{qr}$ ), calculated as $q r=\mathrm{Cr} i \mathrm{~A}$, where $\mathrm{Cr}$ is the runoff coefficient in the pre-urbanization scenario, $i$ is the rainfall intensity fixed as $0.06 \mathrm{~m} / \mathrm{h}$ and $A\left(\mathrm{~m}^{2}\right)$ is the total area of the lot. It is strange that the decree suggests the use of the Manning equation to determine the orifice diameter. 


\begin{tabular}{|c|c|}
\hline \multicolumn{2}{|l|}{ Conclusion } \\
\hline City/Decree & Design guides \\
\hline $\begin{array}{l}\text { Niterói (RJ) } \\
\text { Municipal Law nº } \\
2.630 / 2009\end{array}$ & $\begin{array}{l}\text { Mandatory for impervious areas higher than } 500 \mathrm{~m}^{2} \text {. } \\
\text { Volume is calculated as } V=k A_{I} h \text {, where k referred as an attenuation } \\
\text { coefficient equal to } 0.15, \mathrm{~A}_{1}\left(\mathrm{~m}^{2}\right) \text { is the impervious area, and } \mathrm{h}(\mathrm{m}) \text { is the rain } \\
\text { depth equal to } 0.07 \mathrm{~m} \text {. } \\
\text { - Rain depth does not show the rainfall intensity and duration assumed. }\end{array}$ \\
\hline $\begin{array}{l}\text { Guarulhos (SP) } \\
\text { Municipal Law nº } \\
5.617 / 2000\end{array}$ & $\begin{array}{l}\text { Mandatory, according to the lot area. } \\
\text { Volume is ranging from } 500 \mathrm{~L} \text { to } 3,500 \mathrm{~L} \text { for areas between } 125 \text { and } \\
\text { - } \quad \text { area. } \\
\text { - At the same time the law fixed the volume, its design should be } \\
\text { justified by rain duration, intensity and return period chosen, considering it } \\
\text { gives the higher volume for calculation by a routing flow method. }\end{array}$ \\
\hline $\begin{array}{l}\text { Joinville (SC) } \\
\text { Municipal Decree } n^{\circ} \\
33.767 / 2019\end{array}$ & $\begin{array}{l}\text { OSD is mandatory for lot with higher share of impermeable areas than } \\
\text { permissible. } \\
\text { OSD sizing parameters consider: (i) rainfall intensity of } 144 \mathrm{~mm} / \mathrm{h} \text { for } \\
\text { return period of } 25 \text { years and } 10 \text { minutes rainfall duration, however can } \\
\text { change according to technical analysis; (ii) runoff coefficients for pre- } \\
\text { urbanization }\left(C_{p e r}=0,3\right) \text { and post-urbanization }\left(C_{i m p}=0,9\right) \text {; share of } \\
\text { permeable area; (iii) the orifice discharge diameter is calculated by traditional } \\
\text { equations for orifices; }(\mathrm{v}) \text { The minimum volume of OSD is } 500 \mathrm{~L} \text {. } \\
\text { First the allowed }\left(\mathrm{Q}_{A}\right) \text { and real }\left(\mathrm{Q}_{\mathrm{R}}\right) \text { flowrate are calculated as } Q_{A}= \\
C_{\text {per }} A S_{A}+C_{i m p} A\left(1-S_{A}\right) \text { and } Q_{R}=C_{p e r} A S_{R}+C_{i m p} A\left(1-S_{R}\right) \text { where } S_{A} \text { means } \\
\text { the allowed share of permeable area and } S_{R} \text { is the proposed share for the lot. } \\
\text { Finally, for } Q_{R}>Q_{A} \text { the volume is } V=\left(Q_{R}-Q_{A}\right) t_{c} \text {. }\end{array}$ \\
\hline $\begin{array}{l}\text { Belo Horizonte (MG) } \\
\text { Municipal Law } n^{\circ} \\
\text { 7.166/1996 }\end{array}$ & $\begin{array}{l}\text { OSD should retain } 30 \mathrm{~L} / \mathrm{m}^{2} \text { of the impervious area which exceed the } \\
\text { stablished for the city zone. }\end{array}$ \\
\hline
\end{tabular}

Considering the limitations shown on Brazilian municipalities decrees a new sizing method is proposed that defines the reduction of the peak flow to the preurbanized condition as a criterion for design, as recommended by Drumond, Coelho and Moura (2014). Additionally, it considers the geometry influence and water depth constrains. This objective is achieved by means of simulations with different OSD dimensions, and diameters of the orifice. 


\section{THE OSD DESIGN METHOD}

\subsection{Inflow hydrograph}

As in many similar applications the inflow was determined from the Rational Method, indicated for areas of up to $2 \mathrm{~km}^{2}$ and based on Equation 1 (TUCCl, 2009) as:

$$
Q=\text { C.i.A }
$$

where $Q\left(m^{3} / h\right)$ is the flow rate; $C$ is the runoff coefficient; $i(m / h)$ is the precipitation intensity; $A\left(\mathrm{~m}^{2}\right)$ is the area.

Although simple, such a method is widely used, yielding satisfactory results in flood containment reservoir OSD projects (UDFCD, 2017). Drumond, Moura and Coelho (2018) compared water depths of the OSD considering the Rational Method with experimental results of 48 precipitation events obtaining differences below $19 \%$.

The runoff coefficients were adopted for pre and post-urbanization cases based on Tucci (2009). The definition of the pre-urbanization scenario is based on natural runoff characteristics as a function of soil type as indicated by Peplau and Neves (2014).

Pre- and post-urbanization flows were determined using the Rational Method, with specific runoff coefficients for pre-urbanization ( $\left.C_{\text {pre-urb}}\right)$ and posturbanization ( $\left.C_{\text {pos-urb }}\right)$, according to Equations 2 and 3:

$$
\begin{aligned}
& Q_{\text {pre-urb }}=Q_{\text {pre-urb }} . i . A \\
& Q_{\text {pos-urb }}=Q_{\text {pos-urb. }} \cdot A
\end{aligned}
$$

in which Qpre-urb $\left(\mathrm{m}^{3} / \mathrm{h}\right)$ is the contribution flow of the area in the preurbanization scenario; $Q_{\text {pos-urb }}\left(\mathrm{m}^{3} / \mathrm{h}\right)$ is the contribution flow of the area in the posturbanization scenario; $C_{\text {pre-urb }}$ and $C_{\text {pos-urb }}$ are the runoff coefficients in the pre- and 
post-urbanization scenarios; i $(\mathrm{m} / \mathrm{h})$ is the rainfall intensity; $A\left(\mathrm{~m}^{2}\right)$ is the lot area. These flows correspond, respectively, to the maximum permissible site discharge (the outflow) and the inflows of the flood containment reservoir OSD. The OSD has the proposal function to produce a maximum outflow correspondent to its preurbanization condition after a lot being partially or totally impervious.

The rainfall intensity is determined by intensity-duration-frequency equations developed for local applications.

The return period was established based on Tassi and Villanueva (2004), who studied the costs of OSDs in the urban drainage network. The best efficiency-cost solution achieved for the macro drainage network was the OSD design using 5 years as the return period. Frequently macro drainage design considered higher return periods as 10-50 years and micro drainage systems consider as 2-10 years.

The rainfall duration followed the recommendations of Botelho (1998) where the time of concentration (tc) of the basin is equal to the sum of the time of overland flow (ts) plus 10 minutes.

For impervious areas between 100 and $10,000 \mathrm{~m}^{2}$, the time of overland flow varied between 0.15 and 1.52 minutes, so a general value of 10 minutes was assumed for both the concentration time and the rainfall duration (BOTELHO, 1998; CANHOLI, 2005).

Considering the established hypotheses, the increase in the contribution flow of an area is due to the increase of the impermeable areas (post-urbanization situation), which justifies the OSD design based only in the impervious areas. As indicated by Canholi (2005) and São Paulo (2002), the inflow hydrograph was considered as the simplified triangular hydrograph method based on the Rational Method, that is, an isosceles triangle-shaped hydrograph with a base equal to twice the concentration time. The rainfall is constant, and its duration is also equal the concentration. The peak flow of the hydrograph is the post-urbanization flow rate

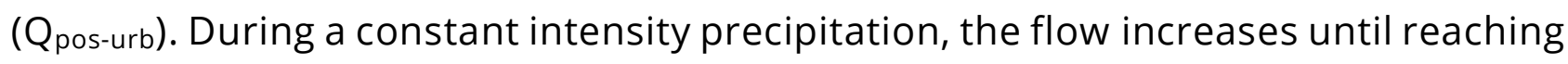


a maximum at the peak of the inflow, when the precipitation ceases and the flow gradually decreases, reaching zero (HONG; YEH; CHEN, 2006).

\subsection{Design criteria}

Barbassa and Campos (2010) studying the hydrological behavior of urban areas stated that the impervious areas works "directly connected". The OSD design was based only on the impervious areas directly connected to the urban drainage network, consequently producing direct runoff, without crossing permeable areas or infiltrating into the soil (GAROTTI, BARBASSA, 2010).

We define the OSD design criteria as a peak flow attenuation efficiency which means that the OSD must compensate the impervious area (post urbanization scenario) bringing the outflow back to its pre urbanization flow rate. The relationship between pre and post urbanization flows is proportional to the runoff coefficients as:

$$
\frac{Q_{\text {pre-urb }}}{Q_{\text {pos-urb }}}=\frac{C_{\text {pre-urb }} \cdot \text { i. } A_{\text {pre-urb }}}{C_{\text {pos-urb }} \cdot \text { i. } A_{\text {pos-urb }}}=\frac{C_{\text {pre-urb }}}{C_{\text {pos-urb }}}
$$

In the equation of the Rational Method (Equation 1) the precipitation intensity value is the same in both scenarios and the permeable area in the preurbanization scenario becomes impermeable in the post-urbanization scenario.

The minimum volume of the OSD was defined by Natural Reservation Loss Method, quoted by Canholi (2005) and adopted by Silva and Cabral (2014). This method proposes that the reservoir volume is equivalent to the reservation volume lost due to urbanization. The minimum volume, $\mathrm{V}_{\min }\left(\mathrm{m}^{3}\right)$, is then calculated from the difference between post and pre urbanization flow rates from a give impervious area (AIMP), connected to the OSD as:

$$
\begin{aligned}
& V_{\text {min }}=\left(Q_{\text {pos-urb }}-Q_{\text {pre-urb }}\right) t \\
& V_{\text {min }}=\left(C_{\text {pos-urb }}-C_{\text {pre-urb }}\right) i A_{I M P} t
\end{aligned}
$$


The volume calculation by itself is not enough and requires more comprehensive studies, analyzing the outflows according to the reservoir dimensions and the discharge structures (TASSI, 2002). Therefore, it is necessary to analyze the flow propagation behavior of the OSD and to achieve the peak flow attenuation efficiency.

Figure 1 presents basic and general geometry of an OSD. The flow regulating orifice, located at the base of the septum, is the hydraulic discharge structure that allows the continuous emptying of the reservoir, and this flow must be by gravity. The septum works as a broad crested weir (spillway) in case the maximum water depth of the reservoir is reached.

Figure 1 - Schematic of an OSD

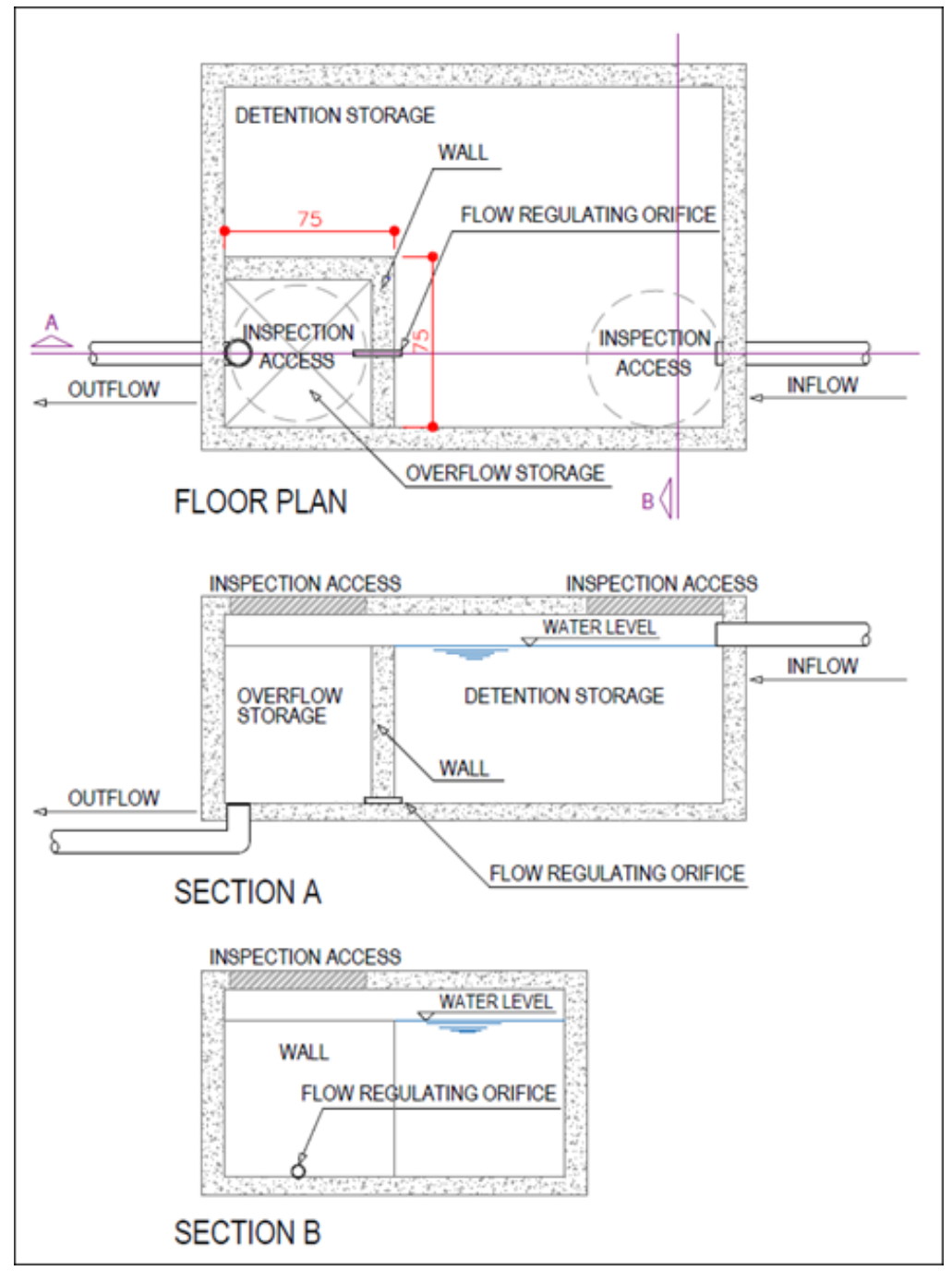

Source: Authors (202)

Ci. e Nat., Santa Maria, v.43, e70, 2021 
The simulation was performed by the Puls method (BROWN; STEIN; WARNER, 2001) as described in the Appendix and solved by trial and error to obtain the peak flow attenuation efficiency set as $1-C_{\text {pre-urb }} / C_{\text {pos-urb. }}$ This procedure was repeated for impervious areas ranging from 100 to $10,000 \mathrm{~m}^{2}$, aiming to establish the best set of design parameters in terms of reservoir volume (base area and height) and discharge orifice diameter. The objective was to establish the lowest volumes possible to meet the desired efficiency, since the reservoir volume is directly associated to the execution costs.

The estimation of the orifice diameter was inspired on the one proposed by Decree $n^{\circ} 176 / 2007$ of the Municipality of Curitiba (CURITIBA, 2007), according to the OSD volume. A new relation based on the impervious area and diameter was proposed as function of the efficiencies and geometries obtained through the simulations routing flow. As described by Cruz, Tucci and Silveira (1998), the combination of the orifice diameter, volume and dimensions has the purpose of obtaining the best set of those parameters to the OSD operation.

In summary the proposed method considered a return period of 5 years, time of concentration and rainfall duration of 10 minutes. The OSD volume is calculated by equation 6 . So, it is necessary do determine the runoff coefficients in a pre and post urbanization scenarios. The orifice diameter and reservoir base area are obtained to achieve a peak attenuation efficiency of $1-C_{\text {pre-urb }} / C_{\text {pos-urb }}$.

\section{RESULTS AND DISCUSSIONS}

We considered the city of Curitiba-PR as a case study for the proposed method. The design rainfall intensity was based on the rainfall intensity-durationfrequency equations for the city of Curitiba-PR, proposed by Fendrich (2003) and presented as:

$$
i=\frac{5726,64 T R^{0,159}}{(t+41)^{1,041}}
$$


in which i $(\mathrm{mm} / \mathrm{h})$ is the intensity of the precipitation; TR (years) is the period of return; $\mathrm{t}(\mathrm{min})$ is the rainfall duration. Considering equation 7 the rainfall intensity obtained is $123.44 \mathrm{~mm} / \mathrm{h}$ for a return time of 5 years and the rainfall duration of 10 minutes. This value is even higher than the one proposed by Curitiba (2007) of $80 \mathrm{~mm} / \mathrm{h}$.

The sedimentary basin of Curitiba-PR is mainly located in the Guabirotuba Formation, which is basically composed of clays, according to a geotechnical mapping study by Talamini Neto (2001) and analysis of the Geological Map of the State of Paraná (MINEROPAR, 2006). The value of 0.25 was adopted for the runoff coefficient, calculated by the average of the expected values for heavy soils with medium slopes and high slopes (TUCCl, 2009). For the post-urbanization scenario, the value of 0.84 was assumed as the average of the expected values for asphalt, concrete, sidewalks and roof surfaces (TUCCI, 2009). These values result in $70 \%$ of the attenuation peak flow.

Figure 2 shows the results of a simulation of the OSD with emphasis on the $70 \%$ attenuation of the peak flow. All the simulations present the same pattern, varying the magnitude of the flows, and whose focus was to determine the peak flows.

Figure 2 - Inflow and outflow hydrograph examples of the OSD for an impervious area of $1000 \mathrm{~m}^{2}$ and $70 \%$ of peak reduction flow

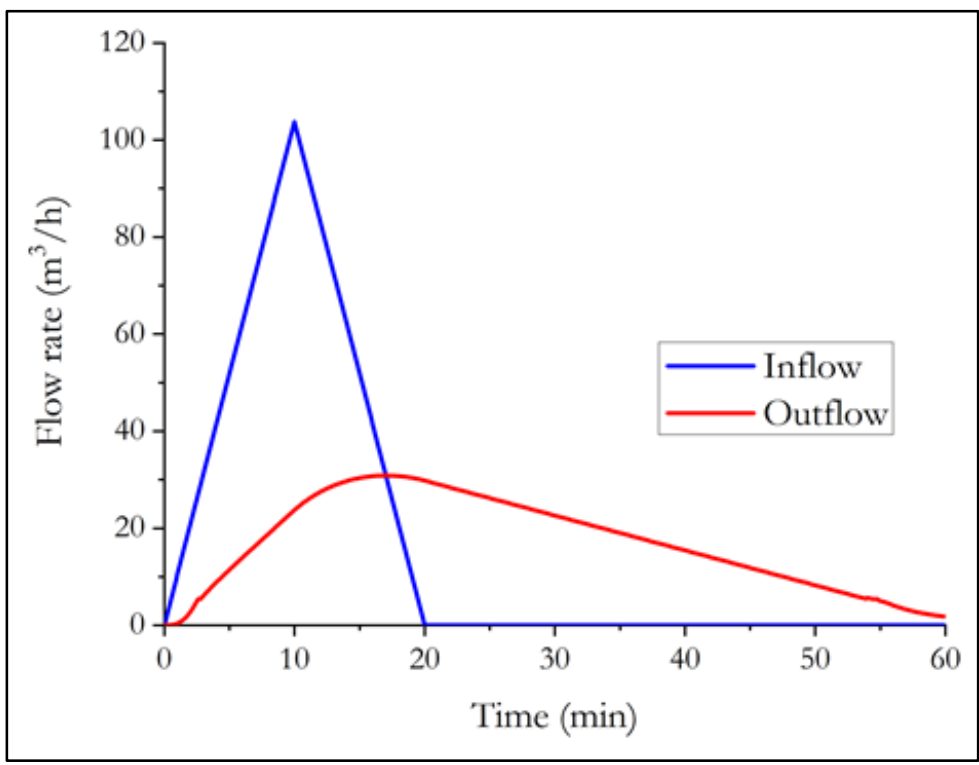

Source: Authors (2020) 
In Figure 3, the results that lead to the new sizing design of the OSD obtained by simulation to meet the criterion of the peak flow attenuation are graphically presented. The diameter of the orifice was increasingly adopted with the increasing of the impervious area (and the inflow rate as well) to balance the base area of the OSD and to meet the desired minimum efficiency peak flow attenuation. Therefore, there is a compromise between the base area, orifice diameter and water depth. An additional constrain was to restrict the maximum water depth (the reservoir high) to $2.70 \mathrm{~m}$, considered to respect maximum and feasible use of the available height in a typical building floor.

For a better understanding the sizing parameters shown in Figure 3, Table 2 synthesizes the diameter of orifice adopted as a function of the impervious area.

Figure 3 - Design parameter of OSD as function of the impervious area. Lines represents parameters as volume, orifice diameter, base area and water depth. The dot line represents the volume considered by Decree $n^{\circ} 176 / 2007$ of the Municipality of Curitiba (CURITIBA, 2007).

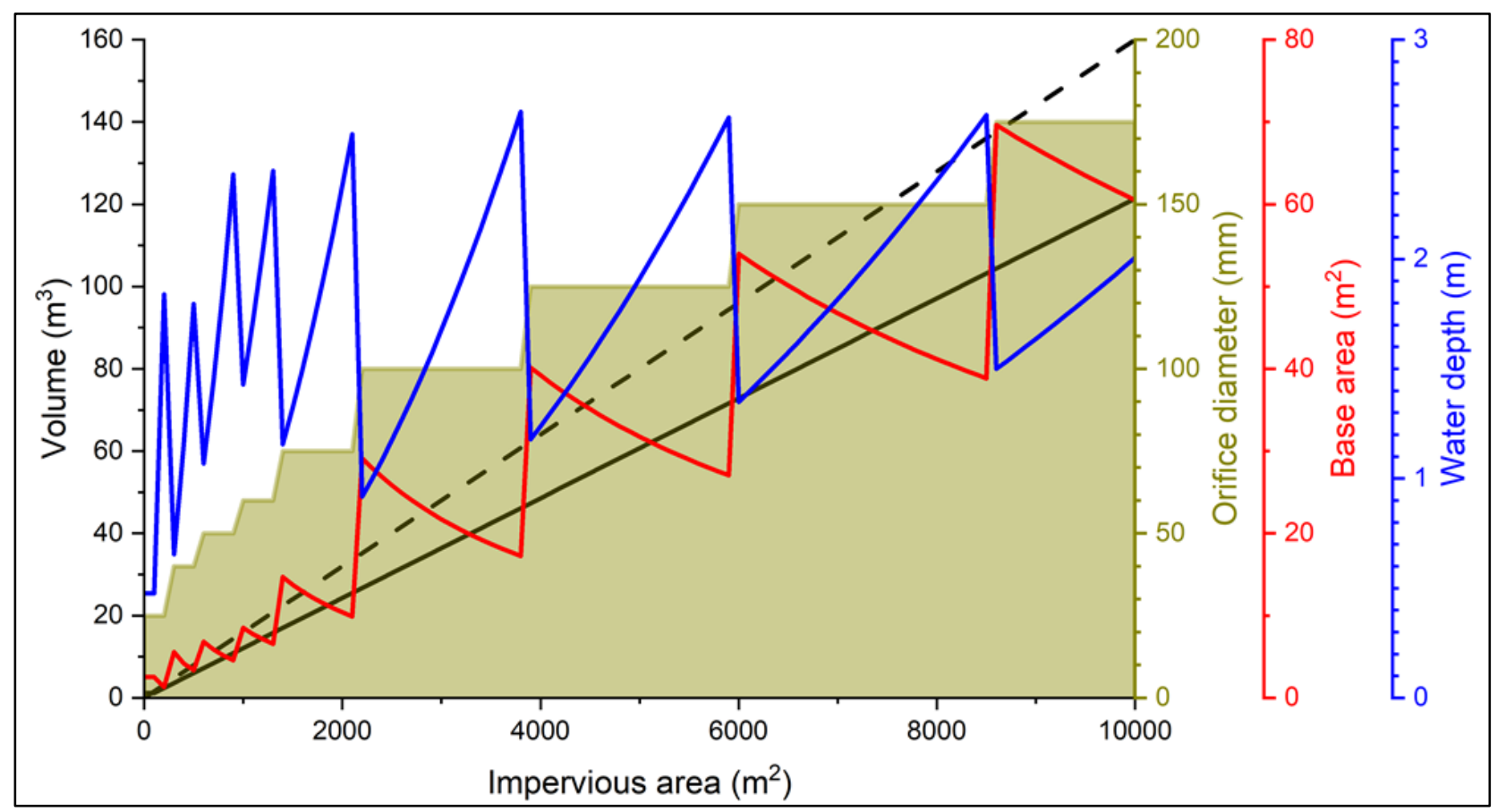

Source: Authors (2020)

Table 2 - Orifice diameter (d) as function of the impervious area (AIMP) 


\begin{tabular}{lccc}
\hline \multicolumn{1}{c}{ A IMP $_{\left(\mathbf{m}^{\mathbf{2}}\right)}$} & $\mathbf{d}(\mathbf{m m})$ & $\mathbf{A}_{\text {IMP }}\left(\mathbf{m}^{\mathbf{2}}\right)$ & $\mathbf{d}(\mathbf{m m})$ \\
\hline $0-100$ & 25 & $1400-2200$ & 75 \\
$100-300$ & 25 & $2200-3900$ & 100 \\
$300-600$ & 40 & $3900-6000$ & 125 \\
$600-1000$ & 50 & $6000-8600$ & 150 \\
$1000-1400$ & 60 & $8600-10000$ & 175 \\
\hline
\end{tabular}

In addition, a general equation to determine the base area was fitted as a function of the impervious area and the orifice diameter

$$
A_{B}=7,1685.10^{-4} d^{3,979} A_{I M P}^{-1}
$$

in which $A_{B}\left(m^{2}\right)$ is the base area of OSD; $d(m m)$ is the orifice diameter and $A_{I M P}\left(m^{2}\right)$ is the impervious area.

Finally, considering $C_{\text {pre-urb }}=0.25, C_{\text {pos-urb }}=0.84, \mathrm{i}=123.44 \mathrm{~mm} / \mathrm{h}$ and $\mathrm{t}=10 \mathrm{~min}$ the volume applied from equation 6 returns

$$
V=0,01214 A_{I M P}
$$

Using the base area value from equation 8 and Table 2 the water depth can be calculated assuming the uniform prism shape by the relationship $h=V / A_{B}$. It is important to highlight that the OSD base geometry is not fixed and can be chosen according to design needs.

The OSD design criteria developed reduces in $24 \%$ the volume defined by the Municipal Decree 176/2007 (CURITIBA, 2007). At the same time the design rainfall increased from $80 \mathrm{~mm} / \mathrm{h}$ to $123 \mathrm{~mm} / \mathrm{h}$, explaining the return period and rainfall duration assumptions. In addition, at the OSD design condition the peak attenuation efficiency is guaranteed while considering the decree sizing criteria it is unknown a priori. This aspect is highlighted in Figure 4 that shows the peak flow attenuation efficiency an OSD volume defined according to the guidelines of the decree, but with different areas of base, which is not a defined criterion. 
Additionally, according to Figure 4, the marginal increase on efficiency decreases with the increase of the base area, justifying the assumption of a minimal efficiency criteria which is not considered in any of the guides shown in Table 1.

Figure 4 - Peak attenuation efficiency for an OSD designed according to the Municipal Decree 176/2007 (CURITIBA, 2007) as function of the base area. The OSD considered $A_{I M P}=100 \mathrm{~m}^{2}, d=25 \mathrm{~mm}$ yielding $V=1.6 \mathrm{~m}^{3}$

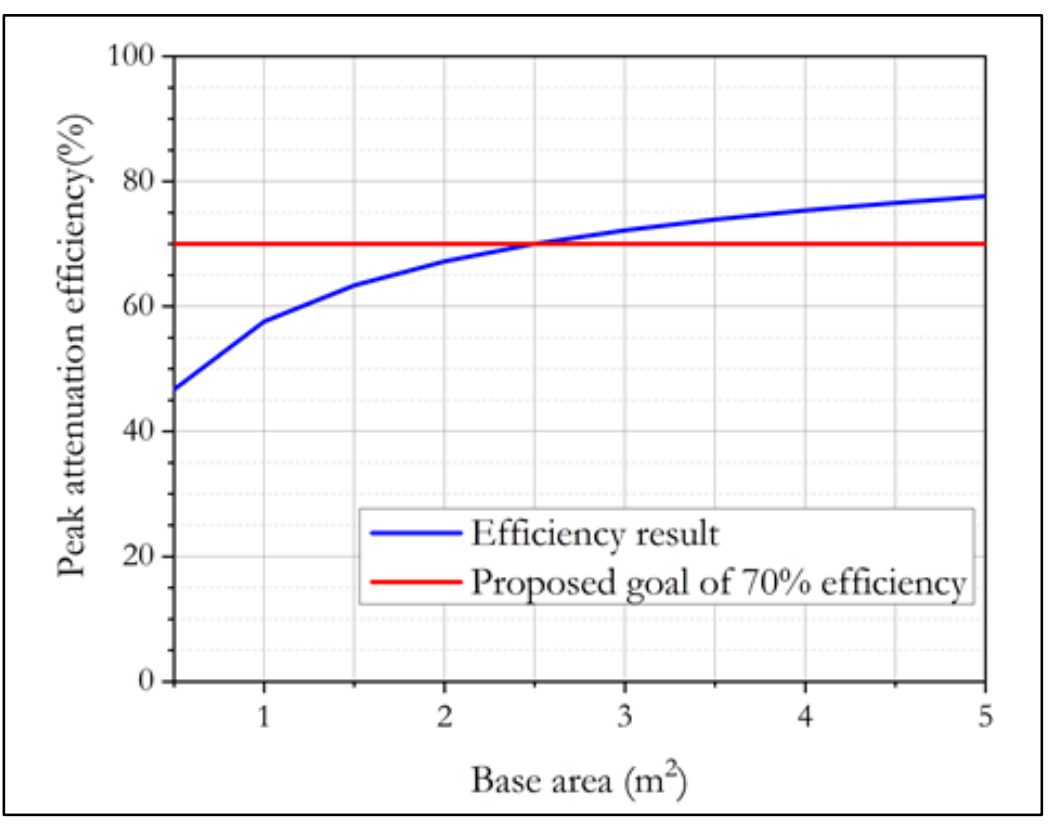

Source: Authors (2020)

\section{CONCLUSION}

This research proposed a new method for OSD design considering a peak attenuation efficiency as the OSD goal. This efficiency was established as a function of the change in the runoff coefficient pre and post-urbanization scenarios This characterization is innovative and can be applied to other localities by defining the runoff coefficients in each case.

Additionally, the efficiency depends on the base area, water depth and orifice diameter. The degrees of freedom for sizing proposal was solved applying the Natural Reservation Loss Method (CANHOLI, 2005) to the OSD volume calculation, 
which is also based on the runoff coefficients and the impervious area. The maximum water depth was set at $2.70 \mathrm{~m}$ for optimization of the area used in a pavement, so these criteria allows manage the OSD position in the building area.

A case study was shown for the city of Curitiba-PR aiming a peak attenuation of $70 \%$ which reduces the volume sizing according to its own legislation in $24 \%$ even considering a higher rainfall intensity for design. Our simulations ensure a better design for short duration rainfalls (when duration is equal to time of concentration), and simulations should be done to verify if it works properly for longer rainfall durations. Besides the case study this method can be applied to other regions considering the specific local parameters.

The OSD volume was calculated by the Natural Reservation Loss Method which considered the reservoir volume as equivalent to the reservation volume lost due to urbanization. This is an interesting concept and can be integrated to proposals of OSD with infiltration reducing even more the peak flow or reducing the base area needed.

Finally, the proposed method can be applied to other locations, considering pre and post-urbanization runoff coefficients, and the rainfall design. The method has the assumptions as limitations and should be considered as a guideline for pre sizing considering the peak attenuation as a main target. Additional simulations can be done to change parameters and include additional or specific restrictions to obtain the better combination of water depth, area and discharge orifice.

\section{REFERENCES}

BARBASSA, A. P.; CAMPOS, J. B. N. (2010). Comportamento hidrológico de áreas urbanas impermeabilizadas diretamente conectadas e total. RBRH: Revista Brasileira de Recursos Hídricos, v. 15, n. 4, p. 69-79, out./dez.

BELO HORIZONTE (Capital). Lei $\mathbf{n}^{\mathbf{0}}$ 7.166, de 27 de agosto de 1996. Estabelece normas e condições para parcelamento, ocupação e uso do solo urbano no município. Prefeitura Municipal de Belo Horizonte, Belo Horizonte, 1996. 
BECCIU, G.; RAIMONDI, A. (2015) Probabilistic analysis of the retention time in stormwater detention facilities. Procedia Engineering, v. 119, p. 1299-1307.

BOTELHO, M. H. C. Águas de chuva: engenharia das águas pluviais nas cidades. 2. ed. São Paulo: Editora Edgard Blücher, 1998.

BROWN, S. A.; STEIN, S. M.; WARNER, J. C. Urban Drainage Design Manual - Hydraulic Engineering Circular 22, Second Edition. Fort Collins: U.S. Department of Transportation Federal Highway Administration, 2001.

CANHOLI, A. P. Drenagem Urbana e Controle de Enchentes. São Paulo: Oficina de Textos, 2005.

CALABRÒ, P. S.; VIVIANI, G. (2006). Simulation of the operation of detention tanks. Water Research, v. 40, p. 83-90, jan.

CAMPISANO, A.; LIBERTO, D.; MODICA, C.; REITANO, S. (2014). Potential for peak flow reduction by rainwater harvesting tanks. Procedia Engineering, v. 89, p. 1507-1514.

COOMBES, P. J.; KUCZERA, G. A.; FROST, A. J.; O'LOUGHLIN, G.; LEES, S. (2003) The impact of rainwater tanks in the Upper Parramatta River Catchment. Australian Journal Of Water Resources, v. 7, p. 121-129.

CRUZ, M. A. S.; TUCCI, C. E. M.; SILVEIRA, A. L. L. (1998).Controle do escoamento com detenção em lotes urbanos. RBRH: Revista Brasileira de Recursos Hídricos, Porto Alegre, v. 3, n. 4, p. 19-31, out./dez.

CUNNINGHAM, A.; COLIBABA, A.; HELLBERG, B.; SILYN ROBERTS, G.; SIMBCOCK, R.; SPEED, S.; VIGAS, N.; WOORTMAN, W. Stormwater management devices in the Auckland region. Auckland Council guideline document, GD2017/001. 2017.

CURITIBA (Capital). Decreto $\mathbf{n}^{\mathbf{0}} \mathbf{1 7 6}$, de 27 de março de 2007. Dispõe sobre os critérios para implantação dos mecanismos de contenção de cheias. Prefeitura Municipal de Curitiba, Curitiba, 2007.

DRUMOND, P. P.; COELHO, M. M. L. P.; MOURA, P. M. (2014). Investigação experimental dos valores de coeficiente de descarga em tubos de saída de microrreservatórios. RBRH: Revista Brasileira de Recursos Hídricos, Porto Alegre, v. 19, n. 2, p. 267-279, abr./jun.

DRUMOND, P. P.; MOURA, P. M.; COELHO, M. M. L. P. (2018). Comparação entre os dados de monitoramento de um microrreservatório e os resultados no uso de métodos teóricos para o seu dimensionamento. RBRH: Revista Brasileira de Recursos Hídricos, Porto Alegre, v. 23, e18, mai.

FENDRICH, R. Chuvas intensas para obras de drenagem no estado do Paraná. 2. ed. Curitiba: Vicentina, 2003. 
GAROTTI, L. M.; BARBASSA, A. P. (2010). Estimativa de área impermeabilizada diretamente conectada e sua utilização como coeficiente de escoamento superficial. Eng. Sanit. Ambient., Rio de Janeiro, v. 15, n. 1, p. 19-28, jan./mar.

GUARULHOS. Lei $\mathbf{n}^{\circ} \mathbf{5 . 6 1 7}$, de 09 de novembro de 2000. Código de obras do Município de Guarulhos. Prefeitura Municipal de Guarulhos, São Paulo, 2000.

GUIMARÃES, L. R. S. Estudo sobre o comportamento hidráulico de vertedouros labirinto [dissertation]. Curitiba: Universidade Federal do Paraná. Curitiba, 2011, 127p.

HONG, Y.; YEH, N.; CHEN, J. (2006). The simplified methods of evaluating detention storage volume for small catchment. Ecological Engineering, v. 26, p. 355-364, jul.

JOINVILLE. Decreto $\mathbf{n}^{\circ}$ 33.767, de 14 de março de 2019. Regulamenta a implantação de mecanismos de contenção de águas pluviais para o processo de conversão da taxa de permeabilidade prevista no art. 76, da Lei Complementar n 470, de 09 de janeiro de 2017. Prefeitura Municipal de Joinville, Santa Catarina, 2019.

MINEROPAR - Serviço Geológico do Paraná (Governo do Estado do Paraná). Mapa Geológico do Paraná. Curitiba, 2006. 1 mapa. Escala 1:650.000. [cited 2018 may 31]. Available from: http://www.mineropar.pr.gov.br/arquivos/File/2_Geral/Geologia/PDF_Mapa_Geo_650000/Map a_Geologico_PR_650000_2006.pdf.

NITERÓI. Lei $\mathbf{n}^{\circ} \mathbf{2 . 6 3 0}$, de 07 de janeiro de 2009. Disciplina os procedimentos relativos ao armazenamento de águas pluviais para reaproveitamento e retardo da descarga na rede pública. Prefeitura Municipal de Niterói, Rio de Janeiro, 2009.

PAIK, K. (2008). Analytical derivation of reservoir routing and hydrological risk evaluation of detention basins. Journal of Hydrology, v. 352, p. 191-201, abr.

PALA, A.; GNECCO, I.; BARBERA, P. (2017). The impact of domestic rainwater harvesting systems in storm water runoff mitigation at the urban block scale. Journal of Environmental Management, v. 191, p. 297-305, abr.

PEPLAU, G. J. R.; NEVES, M. G. F. P. (2014). Análise de critérios para a determinação da vazão de restrição ao escoamento superficial urbano. RBRH: Revista Brasileira de Recursos Hídricos, Porto Alegre, v. 19, n. 4, p. 97-106, out./dez.

PORTO ALEGRE (Capital). Decreto $\mathbf{n}^{\mathbf{0}}$ 18.611, de 09 de abril de 2014. Regulamenta o controle da drenagem urbana e revoga os itens 4.8.6, 4.8.7 e 4.8.9 do Decreto $\mathrm{n}^{\circ} 14.786$, de 30 de dezembro de 2004 - Caderno de Encargos do DEP - e o Decreto n ${ }^{\circ} 15.371$, de 17 de novembro de 2006. Prefeitura Municipal de Porto Alegre, Porto Alegre, 2006.

RECIFE. Lei $\mathbf{n}^{\mathbf{0}} \mathbf{1 8 . 1 1 2}$, de 12 de janeiro de 2015. Dispõe sobre a melhoria da qualidade ambiental das edificações por meio da obrigatoriedade de instalação do "telhado verde", e construção de reservatórios de acúmulo ou de retardo do escoamento das águas pluviais para a rede de drenagem e dá outras providências. Prefeitura Municipal de Recife, Pernambuco, 2015. 
QUEENSLAND Urban Drainage Manual - Third Edition. Brisbane: Queensland Government Institute of Public Works Engineering Australia - Department of Energy and Water Supply, 2013.

RAIMONDI, A.; BECCIU, G. (2014). Probabilistic design of multi-use rainwater tanks. Procedia Engineering, v. 70, p. 1391-1400.

RIO DE JANEIRO (Capital). Decreto n 23.940, de 30 de janeiro de 2004. Torna obrigatório, nos casos previstos, a adoção de reservatórios que permitam o retardo do escoamento das águas pluviais para a rede de drenagem. Prefeitura Municipal do Rio de Janeiro, Rio de Janeiro, 2004.

SÃO PAULO (Capital). Lei $\mathbf{n}^{\mathbf{0}} \mathbf{1 6 . 4 0 2}$, de 22 de março de 2016. Disciplina o parcelamento, o uso e a ocupação do solo no Município de São Paulo, de acordo com a Lei n 16.050, de 31 de julho de 2014 - Plano Diretor Estratégico (PDE). Prefeitura Municipal de São Paulo, São Paulo, 2016.

SÃO PAULO (cidade). Manual de drenagem e manejo de águas pluviais: aspectos tecnológicos; fundamentos. Secretaria Municipal de Desenvolvimento Urbano, 220p, 2012.

SILVA, P. O.; CABRAL, J. J. S. P. (2014). Atenuação de picos de vazão em área problema: estudo comparativo de reservatórios de detenção em lote, em logradouros e em grande área da bacia. RBRH: Revista Brasileira de Recursos Hídricos, Porto Alegre, v. 19, n. 2, p. 7-18, abr./jun.

SILVA JUNIOR, M. A. B.; SILVA, S. R.; CABRAL, J. J. S. P. (2017). Alternativas compensatórias para controle de alagamentos em área urbana com influência das marés no Recife - PE. RBRH: Revista Brasileira de Recursos Hídricos, Porto Alegre, v. 22, e19, jan.

SILVEIRA, A. L. L.; GOLDENFUM, J. A. (2007). Metodologia Generalizada para PréDimensionamento de Dispositivos de Controle Pluvial na Fonte. RBRH: Revista Brasileira de Recursos Hídricos, v. 12, n. 2, p. 157-168, abr/jun.

STERREN, M.; RAHMAN, A. (2015). Single lot on site detention requirements in New South Wales Australia and its relation to holistic storm water management. Sustainability of Water Quality and Ecology, v. 6, p. 48-56, set.

STERREN, M.; RAHMAN, A.; RYAN, G. (2014). Modeling of a lot scale rainwater tank system in XPSWMM: A case study in Western Sydney, Australia. Journal of Environmental Management, v. 141, p. 177-189, ago.

TALAMINI NETO, E. Caracterização geotécnica do subsolo de Curitiba para o planejamento de ocupação do espaço subterrâneo. [dissertation]. Escola de Engenharia de São Carlos, Universidade de São Paulo. 2001, 223p.

TASSI, R. Efeito dos microrreservatórios de lote sobre a macrodrenagem urbana. [dissertation]. Instituto de Pesquisas Hidráulicas, Universidade Federal do Rio Grande do Sul. 2002. 142p.

TASSI, R; VILLANUEVA, A. O. N. (2004). Análise do impacto dos microrreservatórios de lote nos custos de uma rede de drenagem urbana. RBRH: Revista Brasileira de Recursos Hídricos, Porto Alegre, v. 9, n. 3, p. 89-98, jul./set. 
TODESCHINI, S.; PAPIRI, S.; CIAPONI, C. (2012). Performance of stormwater detention tanks for urban drainage systems in northern Italy. Journal of Environmental Management, v. 101, p. 33-45, jun.

TUCCl, C. E. M. Hidrologia: ciência e aplicação. 4. ed. Porto Alegre: ABRH - Editora da Universidade Federal do Rio Grande do Sul, 2009.

UDFCD. Urban Storm Drainage Criteria Manual: Volume 1. Management, Hydrology, and Hydraulics. Denver: Urban Drainage and Flood Control District, 2017.

UDFCD. Urban Storm Drainage Criteria Manual: Volume 3. Best Management Practices. Denver: Urban Drainage and Flood Control District, 2015.

\section{Authorship contributions}

\section{1 - Ricardo Cesar Conrado de Souza}

Former student of the Programa de Pós-Graduação em Engenharia Civil, Universidade Tecnológica Federal do Paraná https://orcid.org/0000-0002-2581-409X - conrado_ricardo@hotmail.com Contribuition: Conceptualization, Formal Analysis, Visualization, Writing - original draft, Writing - review \& editing

\section{2 - Flávio Bentes Freire}

Professor at the Universidade Tecnológica Federal do Paraná, Departamento Acadêmico de Construção Civil https://orcid.org/0000-0002-5459-5578 - freireutfpr@gmail.com Contribuition: Conceptualization, Methodology, Supervision, Writing - original draft

\section{3 - Michael Mannich}

Professor at the Universidade Federal do Paraná, Departamento de Engenharia Ambiental https://orcid.org/0000-0002-5727-2563 - mannich@ufpr.br Contribuition: Conceptualization, Supervision, Visualization, Writing - original draft, Writing - review \& editing

\section{How to quote this article}

FREIRE, F.B.; SOUZA, R.C.C.; MANNICH, M. Design guidelines for on-site stormwater detention. Ciência e Natura, Santa Maria, v. 43, e70, p. 1-20, 2021. Available from:

https://doi.org/10.5902/2179460X63494. 


\section{APPENDIX}

The outflows calculation was based on the Puls Method (BROWN; STEIN; WARNER, 2001), which solves the routing flow in reservoirs according to the continuity equation

$$
\frac{d S}{d t}=I-Q
$$

where $S\left(m^{3}\right)$ is the storage, I $\left(\mathrm{m}^{3} / \mathrm{h}\right)$ is the inflow and $\mathrm{Q}\left(\mathrm{m}^{3} / \mathrm{h}\right)$ is the outflow.

Its discretization generates the equation

$$
\frac{S_{t+\Delta t}-S_{t}}{\Delta t}=\frac{\left(I_{t}+I_{t+\Delta t}\right)}{2}-\frac{\left(Q_{t}+Q_{t+\Delta t}\right)}{2}
$$

where $I_{t}$ and $I_{t+\Delta t}\left(m^{3} / h\right)$ are the inflows into the reservoir at time $t$ and $t+\Delta t, Q_{t}$ and $Q_{t+\Delta t}\left(m^{3} / h\right)$ are the outflows of the reservoir at $t$ and $t+\Delta t, S_{t}$ and $S_{t+\Delta t}\left(m^{3}\right)$ are the storages in $t$ and $t+\Delta t$, $(h)$ is the time interval.

The outflow through the orifice was given by equation

$$
Q_{s}=C_{d} \times A_{0} \times \sqrt{2 \times g \times h_{0}}
$$

where $Q_{s}\left(\mathrm{~m}^{3} / \mathrm{s}\right)$ is the outflow; $C_{d}$ is the discharge coefficient of the orifice in the dimensionless value of 0.6 , as indicated by Canholi (2005) for sharp edges orifices; $A_{0}\left(m^{2}\right)$ is the cross-sectional area of the orifice, $g$ is the acceleration of gravity $(9.81$ $\left.\mathrm{m} / \mathrm{s}^{2}\right)$, and $\mathrm{h}_{0}(\mathrm{~m})$ is the height of the water surface above the central axis of the orifice.

The outflow through the spillway was given by

$$
Q_{s}=C_{v} \times B \times\left(z-z_{k}\right)^{3 / 2}
$$

where $Q_{s}\left(\mathrm{~m}^{3} / \mathrm{s}\right)$ is the outflow; $C_{v}$ is the discharge coefficient of the spillway assumed as 2.0, within the range of values obtained by Guimarães (2011) in tests for spillway of broad crest with flat profile; $B(m)$ is the spillway width assumed to be $1.50 \mathrm{~m}$, considering a square divisor septum with $0.75 \mathrm{~m}$ side, with two sides working as a spillway; $z(m)$ is the water depth, and $z_{k}(m)$ is the height of the spillway crest. 